\title{
Socially sustainable urban renewal in emerging economies: A comparison of Magdolna Quarter, Budapest, Hungary and Albert Park, Durban, South Africa
}

\author{
Ntombifuthi Precious NZIMANDE ${ }^{1}$ and Szabolcs FABULA ${ }^{1}$
}

\begin{abstract}
This study compares the social sustainability of urban renewal interventions in Hungary and South Africa. The societal and environmental challenges arising from urbanisation and the associated population growth in major urban centres around the world have increased the research and policy foci on urban sustainability and governance. While urban regeneration projects are vitally important to urban sustainability, these interventions have been widely criticised because social sustainability issues have been overlooked or ignored. Therefore, there is a need for governance practices that are applicable to different national and urban contexts. The main aim of this study is twofold: firstly, it provides a literature review on the social sustainability of urban renewal and secondly, it compares urban renewal interventions in two different geographical settings to provide recommendations about public participation and stakeholder involvement, which can contribute to increasing social sustainability of urban renewal projects. To this end, a comparative approach was adopted through the analysis of two urban renewal projects: Magdolna Quarter Programme (Budapest, Hungary) and the Albert Park (Durban, South Africa), the data for which were based on a review of secondary sources, including international literature and policy documents. It was found that although urban renewal serves a city-wide purpose (and not just a local one), the socio-economic impacts of these projects have not yet been adequately explored. Furthermore, to achieve higher urban renewal sustainability, there is a need for impact assessments (with special attention paid to the social effects) to promote public participation and empowerment.
\end{abstract}

Keywords: urban renewal, public participation, social sustainability, public-private partnership, Hungary, South Africa

Received May 2020; Accepted October, 2020.

\section{Introduction}

In recent years, sustainability has been firmly integrated into the scientific and policy discourses on urban renewal (e.g. ZHENG, H.W. et al. 2014; Zijun, Y.E. 2019). Since both concepts are concerned with economic, social, and environmental dimensions, integrated urban renewal approaches should be focused on the 'physical, social, economic and ecological aspects of abandoned urban areas through various actions, including redevelopment, rehabilitation, and renovation' (YI, Z. et al. 2017, 1460). Sustainable urban renew- al takes it a step further by integrating the three dimensions of sustainable development with the concept of urban renewal through the involvement and participation of various, bottom-up multi-stakeholders (Zijun, Y.E. 2019). However, social sustainability aspects have often been neglected in urban renewal schemes (DARCHEN, S. and LADOUCEUR, E. 2013; JIN, E. et al. 2018), primarily because of different stakeholder aims and policies.

Some authors argue that public-private partnerships (PPPs) are effective instruments to include various stakeholders and carry out socially sustainable urban renewal projects

\footnotetext{
${ }^{1}$ Department of Economic and Human Geography, University of Szeged. H-6722 Szeged, Hungary.

E-mails: ntombifuthi.nzimande@geo.u-szeged.hu; fabula.szabolcs@gmail.com
} 
(e.g. Colantonio, A. et al. 2009). However, successful operation of PPPs is often hindered by conflicts over decision making, and inadequate cooperation schemes can easily result in the exclusion of less powerful interest groups from the urban renewal process. The operation of PPPs in urban renewal is undoubtedly a geographical question, inasmuch as PPPs are influenced by, for example, national- and locallevel regulations, politics of scale, and placespecific attributes (e.g. population composition) of the effected neighbourhoods. Hence the need for studies that reveal what practices in social participation and involvement can lead to socially sustainable urban renewal in significantly different geographical contexts.

The main aim of our study is twofold. First, it provides a literature review on the social sustainability of urban renewal. Second, it compares urban renewal interventions in two different geographical settings to provide recommendations about public participation and stakeholder involvement, which can contribute to increasing social sustainability of urban renewal projects.

Accordingly, the research questions addressed in this paper are the following:

a) How can the concept of social sustainability be defined with regards to urban renewal?

b) What is the relationship between the social sustainability of urban renewal interventions and the involvement and participation of various stakeholders?

c) What lessons can be learnt with relation to social sustainability from urban renewal projects implemented in different geographical contexts?

For these purposes, a comparative approach was adopted through the analysis of two urban renewal projects: Magdolna Quarter Programme (District VIII, Budapest, Hungary) and the Albert Park (Inner city, Durban, South Africa), the data for which were based on a review of secondary sources, including international literature and policy documents. Although these interventions were carried out in different geographical contexts, they show certain similarities, serving with relevant lessons to social sustainability, stakeholder involvement and public participation.

\section{Social sustainability and urban renewal: international trends}

In recent years, increased attention has been paid in academic discourses to the social sustainability of urban renewal (GLAsson, J. and Wood, G. 2009; Lee, G.K.L. and Chan, E.H.W. 2010; Dempsey, N. et al. 2011; Wong, L.K. and YU, P.H. 2015). Yet, unlike economic and environmental sustainability, social sustainability has not been clearly defined as part of urban renewal and therefore has not been treated as an equally important component of sustainable development. In addition, as social sustainability definitions vary based on the researcher's field of study and profession (Table 1), there is no universally accepted criteria for social sustainability, which means that this area has been under-theorised and over-

Table 1. Some definitions of social sustainability

\begin{tabular}{l|l}
\hline \multicolumn{1}{c|}{ Definition } & \multicolumn{1}{c}{ Reference } \\
\hline $\begin{array}{l}\text {.. refers to the impacts of urban infrastructure on the affordability } \\
\text { of and access to public service delivery by poorer groups within } \\
\text { urban society. }\end{array}$ & $\begin{array}{l}\text { RoselAND, M. (1998) in KopPENJAN, J.F. } \\
\text { and ENSERINK, B. (2009, 284) }\end{array}$ \\
\hline $\begin{array}{l}\text {.. is a life-enhancing condition within communities, and a process } \\
\text { within communities that can achieve that condition. }\end{array}$ & MCKENZIE, S. (2004, 12) \\
\hline $\begin{array}{l}\text {.. is a quality of societies. It signifies the nature-society relationships, } \\
\text { mediated by work, as well as relationships within society. }\end{array}$ & GRIESSLER, E. and LITTIG, B. (2005, 11) \\
\hline $\begin{array}{l}\text {.. blends traditional social policy areas and principles, such as } \\
\text { equity and health, with emerging issues concerning participation, } \\
\text { needs, social capital, the economy, the environment, and, more re- } \\
\text { cently, with the notions of happiness, well-being and quality of life. }\end{array}$ & ColANTONIO, A. (2011, 40) \\
\hline
\end{tabular}


simplified in existing theories. Most of the definitions indicate that social sustainability has several dimensions and influencing factors, such as accessibility of public services, employment, social capital and community wellbeing, sense of community and belonging. Furthermore, an important aspect of social sustainability in urban renewal is social participation and democratic involvement. Thus, as several scholars argue, the process of urban regeneration should always include the mobilisation of potential stakeholders and the capacity building of the local community (DEMPSEY, N. et al. 2011; Holden, M. 2011, 2012).

As such, many cities are taking a bottomup approach to urban renewal projects by actively encouraging public participation, social interaction, and cultural revitalisation (Ho, D.C.W. et al. 2012). However, despite these efforts, national and local governments in many countries still struggle with the conceptualisation and implementation of socially sustainable urban renewal, and policies for democratic involvement and community participation are not always effective.

There are several ways that stakeholders can be involved in urban renewal projects, one of which is through public-private partnerships (PPPs). Similar to social sustainability, PPP does not have a universally accepted definition, as it is an umbrella term, involving a wide range of concepts, and having different meanings in different geographical contexts. Nevertheless, for the purpose of our study, PPP is defined as a 'co-operation between public and private actors with a durable character in which actors develop mutual products and/or services and in which risk, costs, and benefits are shared' (KLIJN, E.H. and Teisman, G.R. 2003, 137).

In recent decades, PPPs have been seen to be a solution for budget-and-time constraints, especially in large projects (WARSEN, R. et al. 2018). However, the successful operation of PPPs in urban renewal has often been hindered by joint stakeholder decision-making processes, which has hampered the social sustainability of these projects. Grounded in experience from three Dutch case studies,
Klijn, E.H. and Teisman, G.R. (2003) argued that problems usually arose when there were many stakeholders and an assumption of co-operation and interdependency, which more often than not resulted in failure, from which it was concluded that public and private sector contractual relationships are needed to focus all relevant stakeholders on the common goal. From a study in Jakarta, RAHARDJo, H.A. et al. (2014) strongly advised that for PPP urban renewal projects to succeed, community members and non-profit organisations needed to be encouraged to participate. Mendel, S.C. and Brudney, J.L. (2012) found that non-profit organisations in Cleveland, United States, provided a 'third-space' where local people were able to voluntarily integrate with key stakeholders to tackle the challenges arising in different phases of an urban renewal project. Although PPPs are complex and difficult to implement, they have been found to result in faster and more efficient community service delivery (Houghton, J. 2011). Nonetheless, there is still less focus on social sustainability and the social participation in many urban renewal projects, and as conditions for public participation differ by country, emphasis is needed on international comparison when investigating urban renewal PPPs.

Relatively few studies have compared urban renewal projects from at least two different continents through the lens of social sustainability. In a review of urban sustainability achievements in different cultural development models in Brazil, India and Mexico, Basiago, A.D. (1998) concluded that projects could be simultaneously economically, environmentally and socially sustainable. KRIŽNIK, B. (2018) also compared institutional and planning approaches and social sustainability in urban development and regeneration projects in Barcelona, Spain and Seoul, South Korea, finding that despite community involvement being one of the key dimensions of social sustainability and the main focus of both projects being to meet the needs of all citizens, only a few selected social groups benefitted. 
In a similar vein, comparing participatory urban regeneration projects in Japan and Denmark, Harada, Y. and Jørgensen, G. (2016) emphasise the importance of international comparative research as a mutual learning process. The argument here is that geography does matter in this respect as national and local circumstances (e.g. welfare system, policy context of urban regeneration) significantly influence PPPs. Hence the need for international comparative studies that investigate urban renewal PPPs in very different geographical contexts (and not only in economic core regions and western countries) and provide general lessons about how to make these urban renewal schemes more socially sustainable.

\section{Case study selection}

One of the main aims of this paper is to provide lessons for urban research and policy with regards to public participation and social sustainability of urban renewal. These lessons should be applicable to projects situated in different geographical contexts. Hence we compare two interventions from two different countries, different continents (Hungary and South Africa). Despite apparent differences, these two cases show considerable similarities as well:

(i) historical development path of the two societies: they both experienced dictatorship (although apartheid in SA was a racist one, in Hungary the regime was based on communist ideology and thus rejected the idea of social difference), and in both countries democratic social order and market capitalism have been built from early 1990s;

(ii) in the past both case-study areas were disadvantaged, crime-ridden neighbourhoods with stubborn negative image, but due to recent renewal activities they are under transformation;

(iii) both interventions were run by PPP cooperation schemes, and in both cases, international funds (EU) influenced the objectives and governance schemes of the two projects, fostering public participation and thus social sustainability.

\section{National policy contexts}

\section{Hungary}

In Hungary, urban renewal PPPs only became possible after the collapse of the Marxist-Leninist dictatorship in 1990. Before the 1990s, housing allocation was dominated by state-ownership and central bureaucratic coordination, whereas urban reconstruction referred mainly to the building of prefabricated housing estates using greenfield construction or by demolishing and replacing pre-existing old apartments in some areas. This process led to disinvestment and dilapidation in many inner-city neighbourhoods, especially in Budapest, which resulted in very poorquality housing stock in the affected areas (SZelényi, I. 1990; Lichtenberger, E. et al. 1995). Furthermore, due to the selective liberalisation of the state-led command economy during the 1970s and 1980s, private investment and segmentation began to emerge in the housing sector (BodNÁr, J. and Böröcz, J. 1998), coupled with social differentiation and segregation in inner-city neighbourhoods prior to 1990 (Kovács, Z. 2009).

After 1990, urban regeneration activities were profoundly influenced by the shift from a socialist state-led command economy to a liberal market economy, and by the transformation from a centralised single-party state to a democratic unitary state. The public administration system was decentralised, granting extensive autonomy for local municipalities in settlement development (Act LXV of 1990/ Act CLXXXIX of 2011 on Local Governments). Budapest is unique in this respect, as in the capital city a two-tier self-government system has been established, including the Municipality of Budapest (i.e. City Hall) and the 23 district municipalities with special legal status (Table 2). Thus, since 1990 the tasks and responsibilities have been divided between the district municipalities and the Municipality of Budapest, and the decision-making power of the former is still highly independent of the Budapest City Hall (Tosics, I. 2006; EnYedI, Gy. and PÁlné Kovács, I. 2008). 
Table 2. Major policies, strategies and plans that have shaped urban renewal policies in Hungary*

\begin{tabular}{|c|c|c|c|}
\hline $\begin{array}{l}\text { SUPRANATIONAL } \\
\text { POLICIES AND } \\
\text { STRATEGIES }\end{array}$ & $\begin{array}{l}\text { NATIONAL POLICIES } \\
\text { AND STRATEGIES }\end{array}$ & $\begin{array}{l}\text { BUDAPEST REGIONAL } \\
\text { POLICIES }\end{array}$ & $\begin{array}{l}\text { JÓZSEFVÁROS } \\
\text { PLANS AND } \\
\text { STRATEGIES }\end{array}$ \\
\hline $\begin{array}{l}\text { European Union } 2020 \\
\text { Strategy }\end{array}$ & $\begin{array}{l}\text { Fundamental Law of } \\
\text { Hungary }\end{array}$ & \multicolumn{2}{|c|}{ Integrated Urban Development Strategy } \\
\hline $\begin{array}{l}\text { European Regional } \\
\text { Development Fund }\end{array}$ & $\begin{array}{l}\text { National Framework } \\
\text { Strategy on Sustainable } \\
\text { Development }\end{array}$ & $\begin{array}{l}\text { Long-Term Urban } \\
\text { Development Concept } \\
2030\end{array}$ & $\begin{array}{l}\text { District Development } \\
\text { Strategy }\end{array}$ \\
\hline Leipzig Charter of 2007 & $\begin{array}{l}\text { National Strategic } \\
\text { Reference Framework } \\
\text { 2007-2013 }\end{array}$ & $\begin{array}{l}\text { Budapest Agglomeration } \\
\text { Spatial Plan }\end{array}$ & $\begin{array}{l}\text { Act LXXIV of } 2016 \text { on } \\
\text { Townscape Protection }\end{array}$ \\
\hline \multirow[t]{4}{*}{ Territorial Agenda } & $\begin{array}{l}\text { Integrated Urban } \\
\text { Development Framework }\end{array}$ & & \\
\hline & $\begin{array}{l}\text { Competitive Central } \\
\text { Hungary Operational } \\
\text { Programme 2014-2020 }\end{array}$ & & \\
\hline & $\begin{array}{l}\text { New Széchenyi Plan } \\
\text { 2014-2020 }\end{array}$ & & \\
\hline & $\begin{array}{l}\text { National Development } \\
\text { and Territorial } \\
\text { Development Concep }\end{array}$ & & \\
\hline
\end{tabular}

${ }^{*}$ Compiled by the authors.

The decentralisation of public administration provided local municipalities with the right to create their own development strategies, land use plans and building regulations, still adhering to national-level policy frameworks. However, due to their limited financial resources, privatisation of the former public housing stock was a common practice amongst local governments throughout the 1990s and 2000s, and this process was supported by national regulation (e.g. Act LXXVIII of 1993). As a result, public housing share dropped markedly; for example, between 1990 and 2006, it decreased from 51 per cent to 8 per cent in Budapest (Kovács, Z. and Herfert, G. 2012), still showing considerable unevenness amongst the districts, e.g. in the $8^{\text {th }}$ district this figure was 10 per cent in 2017. The liberalisation of the Hungarian economy also resulted in a massive FDI influx from the 1990s, and it facilitated investments in office-space and housing, particularly in Budapest (Földi, Z. and Kovács, Z. 2014). However, while the necessary conditions for PPPs were set, such interventions were relatively rare before the 2000 s, as the urban rehabilitation projects were mostly financed by local municipalities (e.g. Budapest Urban Rehabilitation Fund, established in 1994).

Urban renewal PPPs spread in Hungary during the 2000s, which coincided with the country's EU-accession and the consequent incorporation of EU urban planning policies into Hungarian legislation. Joining the EU in 2004 opened the door to community-wide initiatives and networks, such as the URBAN, the URBACT, the EUKN and the Leipzig Charter on Sustainable European Cities. The 'integrated urban intervention' idea was also adopted at this time, which led to the introduction of the 'social urban rehabilitation' and 'socially sensitive urban renewal' concepts (GERôHÁzI, É. et al. 2004). The best example of this type of intervention was the Magdolna Quarter Programme (MQP) in Józsefváros, District VIII of Budapest. This programme was managed by Rév8, which company was established by the local gov- 
ernment, but the OTP (the most important savings bank in the socialist state, which was privatised after 1990) and Budapest Municipality also had shares in it. Even though a social urban rehabilitation model had been developed, there was a considerable diversity amongst urban renewal interventions in Hungary, in terms of management schemes and financing (see Csanádi, G. et al. 2011; Keresztély, K. and Scott, J.W. 2012).

After 2010, the political circumstances of urban renewal changed significantly due to an authoritarian turn and massive re-centralisation in policy making, implemented by the Fidesz-government. At the same time, the country's share of EU financial transfers increased; for example, almost EUR 17,000 million from the Cohesion Fund and European Research and Development Fund was allocated to Hungary for the 2014-2020 programming period, from which approximately 5 per cent was dedicated to the 'sustainable urban development' of the cities with 'country seat' status, $1 / 5$ of which was to be spent on urban rehabilitation (JELINEK, C. 2017). Due to the political re-centralisation, while the planning and design of local (spatial) development remained with local municipalities, the delivery of many public services crucial to social inclusion (e.g. primary and secondary schools) were transferred to central government bodies (Teller, N. 2015). Therefore, the local municipalities prepared integrated development strategies (although it was not obligatory for smaller municipalities), which served as the development project frameworks for the allocation of EU and national financial resources. While these integrated development strategies also included anti-segregation programmes, as JELINEK, C. (2017) argued, urban rehabilitation became an instrument for handling social tensions at the local level.

\section{South Africa}

During the apartheid era in South Africa, the majority of the population (Blacks, Indians and Coloureds) lived in harsh, impoverished conditions, were excluded from the mainstream economy, and were provided with limited basic services because of the segregation laws (such as Group Areas Act of 1950). The spatial divisions placed the white people in affluent communities and the Blacks, Coloureds' and Indians in segregated areas on the city outskirts. Due to deindustrialisation and the rapid urbanisation in the 1970s, there were severely deteriorating buildings in the centres of many large cities, which became even worse after the apartheid regime was dismantled in the mid-to-late 1990s as a majority of the white and middle-income inhabitants fled the innercity districts to the more affluent suburban areas. Coupled with the withdrawal of property investment and a lack of good transport and administrative systems, the inner cities experienced an increase in abandoned buildings, which resulted in many buildings being illegally rented or being squatted in (FrEnZEL, F. 2014). As such, many inner cities in South Africa have been going through a 'transformation process since the faltering years of apartheid' (Frenzel, F. 2014, 437).

South Africa's first democratic elections were held in 1994 when the new African National Congress government led by former President Nelson Mandela won the elections. Many legislative policies were consequently introduced and implemented by successive post-apartheid ANC governments to correct the imbalances and injustices of the apartheid era (Table 3). One of the main objectives of these policies was to renew and develop the social, economic and environmental states of the dilapidated urban regions. Twenty-five years after the dismantling of the apartheid regime, human settlement and urban development continues to be a major socio-economic challenge in South Africa.

After the South African cabinet approved the request for the development of a regulatory framework for PPP in 1997, an interdepartmental task team was appointed to determine how PPP could be used to improve service delivery, and four months after the release of the team's document in December 1999, the strategic framework for PPP was en- 
Table 3. Key recent and relevant development plans in South Africa*

\begin{tabular}{|c|c|c|c|}
\hline $\begin{array}{c}\text { INTERNATIONAL } \\
\text { POLICIES AND } \\
\text { STRATEGIES }\end{array}$ & $\begin{array}{l}\text { NATIONAL POLICIES AND } \\
\text { STRATEGIES }\end{array}$ & $\begin{array}{l}\text { KWAZULU-NATAL } \\
\text { REGIONAL POLICIES }\end{array}$ & $\begin{array}{l}\text { DISTRICT PLANS AND } \\
\text { POLICIESES }\end{array}$ \\
\hline $\begin{array}{l}\text { Sustainable } \\
\text { Development Goals }\end{array}$ & Constitution of South Africa & $\begin{array}{l}\text { Spatial Development } \\
\text { Framework }\end{array}$ & $\begin{array}{l}\text { Integrated Development } \\
\text { Plan }\end{array}$ \\
\hline $\begin{array}{l}\text { African Union } \\
\text { Agenda } 2063\end{array}$ & $\begin{array}{l}\text { Redistribution and } \\
\text { Development Programme }\end{array}$ & State of the Province & $\begin{array}{l}100 \text { Resilient Cities } \\
\text { Strategy }\end{array}$ \\
\hline \multirow[t]{6}{*}{ New Urban Agenda } & $\begin{array}{l}\text { National Urban Renewal } \\
\text { Framework }\end{array}$ & $\begin{array}{l}\text { Provincial Growth and } \\
\text { Development Plan }\end{array}$ & $\begin{array}{l}\text { Long-Term Development } \\
\text { Framework }\end{array}$ \\
\hline & $\begin{array}{l}\text { Breaking New Ground } \\
\text { Housing Delivery, } 2005 \\
\end{array}$ & & \\
\hline & $\begin{array}{l}\text { Integrated Urban } \\
\text { Development Framework }\end{array}$ & & \\
\hline & National Development Plan & & \\
\hline & $\begin{array}{l}\text { District Development } \\
\text { Model }\end{array}$ & & \\
\hline & $\begin{array}{l}\text { National Spatial } \\
\text { Development Framework }\end{array}$ & & \\
\hline
\end{tabular}

${ }^{*}$ Compiled by the authors.

dorsed and the national treasury published regulations for the management and maintenance of the PPP. Despite the low number of PPP projects, the South African government has continued to adopt, revise and amend the multiple urban planning and regeneration policies to reverse the damage left by the apartheid government. Many of these policies were adapted from post-industrial city models from the United Kingdom because of their emphasis on creativity and culture. However, of all the policies, the amendment to the Income Tax Act 58 of 1962 to include an Urban Development Zone tax incentive in 2004 was one of most important steps in encouraging private sector led businesses to invest in the construction and development of commercial and residential buildings in the demarcated UDZs (South African Revenue Service, 2014; Gregory, J.J. 2016; Young, J. 2018).

During his State of the Nation Address in 2001, former President Thabo Mbeki introduced the Urban Renewal Programme and the Integrated Sustainable Rural Development Programme, saying that the main purpose of these programmes was for the government to 'conduct a sustained campaign against rural and urban poverty and underdevelopment, (by) bringing in the resources of all three spheres of government in a coordinated manner' (SONA, 2001). Eight presidential nodes in five different provinces across the country were selected to act as pilot projects for the implementation of the social urban renewal programmes and to assess the benefits of these projects on the beneficiaries in all nodes (MusaKwa, W. 2008; Donaldson, R. and du Plessis, D. 2013; Mhlekude, N. 2013; Ndlela, A.P. 2013; Mbanjwa, P. 2018). The main concerns raised in all these studies were the lack of meaningful community involvement, engagement or participation, the lack of transparency between the government officials, the lack of coherence in the capacity building policies, the weak leadership management, the unclear project mandates and the exclusion of local businesses, non-government organisations and community leaders. In places where these issues persisted, the communities became despondent and no sense of community belonging was evident.

As such, the South African government recognised and acknowledged the shortfalls and adopted a new programme, the National Development Plan (NDP) Vision 2030, which 
is an overarching long-term plan that seeks to eradicate poverty and eliminate inequality. The NDP seeks to involve all relevant stakeholders to create a more stable country and to ensure equal access to the opportunities in the urban areas. Furthermore, as a response to the above-mentioned issues and former President Jacob Zuma's call for the need of an urban strategy to respond to the rapid urbanisation, the Integrated Urban Development Framework (IUDF) was developed and approved by the Cabinet in 2016. The IUDF builds on the UN Sustainable Development Goals 11 and NDP by seeking to retrofit the existing cities footprint to produce cities that are connected, coordinated and compact. To complement the IUDF, President Cyril Ramaphosa went on to introduce the District Development Model (DDM) in a bid to curb the silo mentality in which different spheres of government operated. The DDM was approved in 2019 and aimed at mobilising communities, NGOs, and private sector organisations into achieving social compact.

\section{Case study description}

This sub-section outlines the two specific projects: Magdolna Quarter Programme in Budapest and Albert Park in Durban (Figure 1).

\section{Magdolna Quarter Programme (MQP)}

The Magdolna Quarter (in Hungarian: Magdolna Negyed) is a sub-district in the administrative area of Józsefváros (District VIII in Budapest), bordered by the Corvin Promenade, the elite Palace Quarter and a major railway station.

There were three phases in the MQP, each of which was funded by multiple stakeholders. The first phase from 2005-2008 was funded by the Municipality of Budapest and the Municipality of Józsefváros and had a total budget of EUR 3.2 million, most of which was for the partial renovation of four municipalityowned housing blocks and associated projects. The second phase from 2008-2011 was fund-
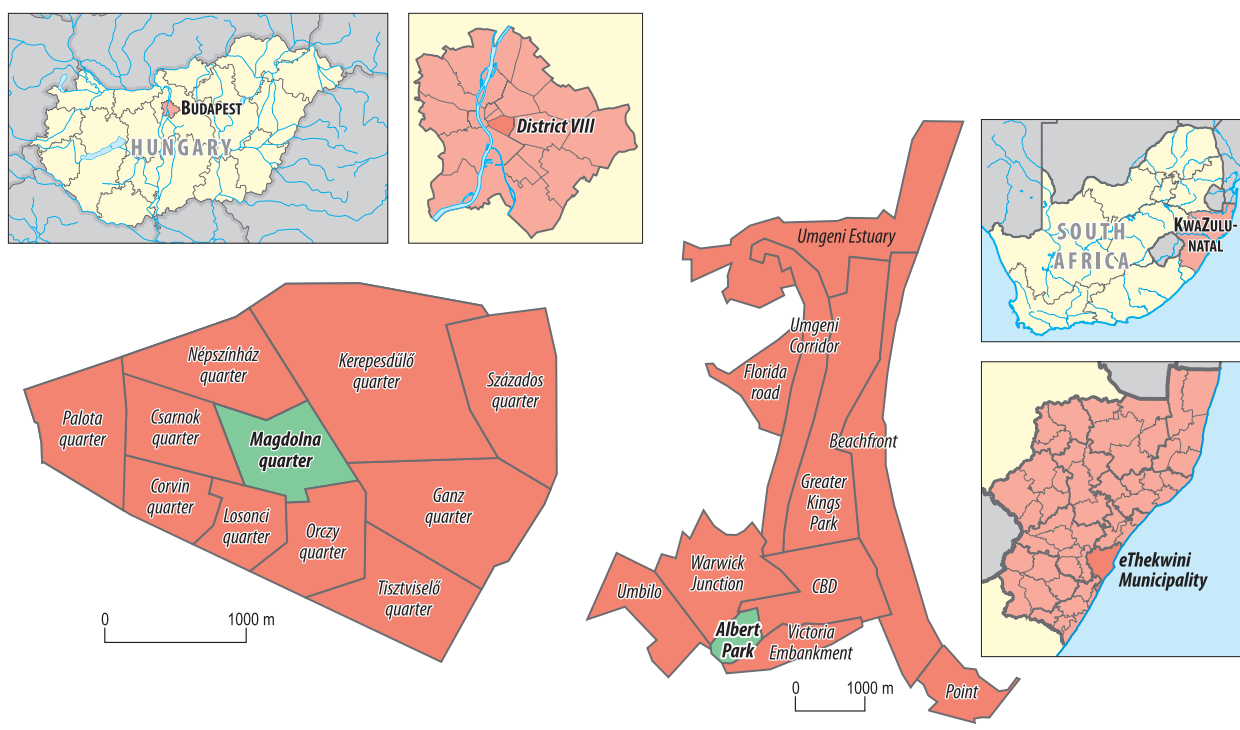

Fig. 1. Location map of Magdolna Quarter inside District VIII in Budapest (left), and Albert Park inside the Inner city of Durban (right). 
ed by the European Regional Development Funding (ERDF) and had a total budget of EUR 7.2 million, with the primary project elements being focused on the revitalisation of public spaces. The third phase, between 2013 and 2015, was funded by the ERDF and European Social Fund (ESF) and had a total budget of EUR 13.9 million, most of which was for a community centre and associated project elements (see Locsmándi, G. 2011; Keresztély, K. 2017).

There were seven projects in the MQP:

- the development of a community centre from the glove factory,

- the improvement of public spaces,

- the development of economic and employment opportunities,

- the improvement of educational facilities,

- the regeneration of housing flats,

- the development of crime prevention programmes, and

- the establishment of social cohesion services.

The aim of these programmes was to integrate community members into the local planning of their area. Through this citizen participation, the authorities sought to make the Magdolna Quarter unique by encouraging the citizens to remain in the area and not relocate. The Teleki Square project (Photos 1 and 2), implemented in the third phase of MQP, was initiated by the Újirány Csoport (New Direction Group) for the public park rehabilitation planning procedure. This square was historically a 'motley centre' (AlföLdi, G. et al. 2019, 163) for newly arrived immigrants in the city, and later became a stigmatised crime ridden, functionless area.

\section{Albert Park}

Albert Park is located in the south-eastern part of Durban, and is bounded by Anton Lembede Street to the North, Dr Yusuf Dadoo Street to the East, Diakonia Avenue to the South and Joseph Nduli Street to the West, and was named after the large Albert Park in the area, which is also known as 'Whoonga Park' (Photos 3 and 4).

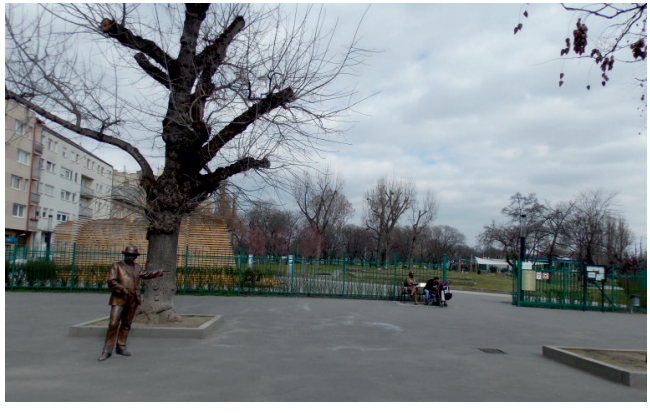

Photo 1. The Teleki Square after rehabilitation (Photo by Fabula, Sz.)

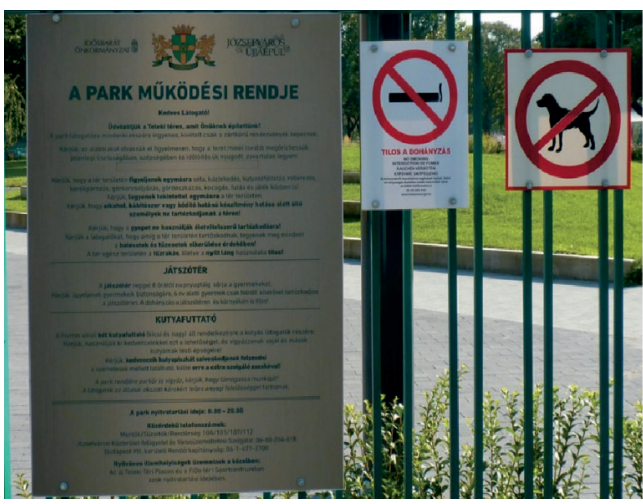

Photo 2. Park rules of the Teleki Square after rehabilitation (Photo by Boros, L.)

As part of the Inner City Thekwini Regeneration and Urban Management Programme (iTRUMP) that was established in the late 1990s in the quest to make Durban a sustainable city, a cultural precinct was created in Albert Park where 'a cosmetic facelift of palm trees' (ERwin, K. 2018, 34) were planted in the middle of an island of buildings, new street lights were installed and an outdoor stage was built for the Durban music school. Additionally, historic buildings were renovated such as Diakonia Centre which houses various NGOs, the Durban Music School, and a small museum.

Furthermore, Albert Park is characterised by the two main streets: Diakonia Avenue and the Maud Mfusi Street: which are vastly different from each other. Diakonia Avenue 

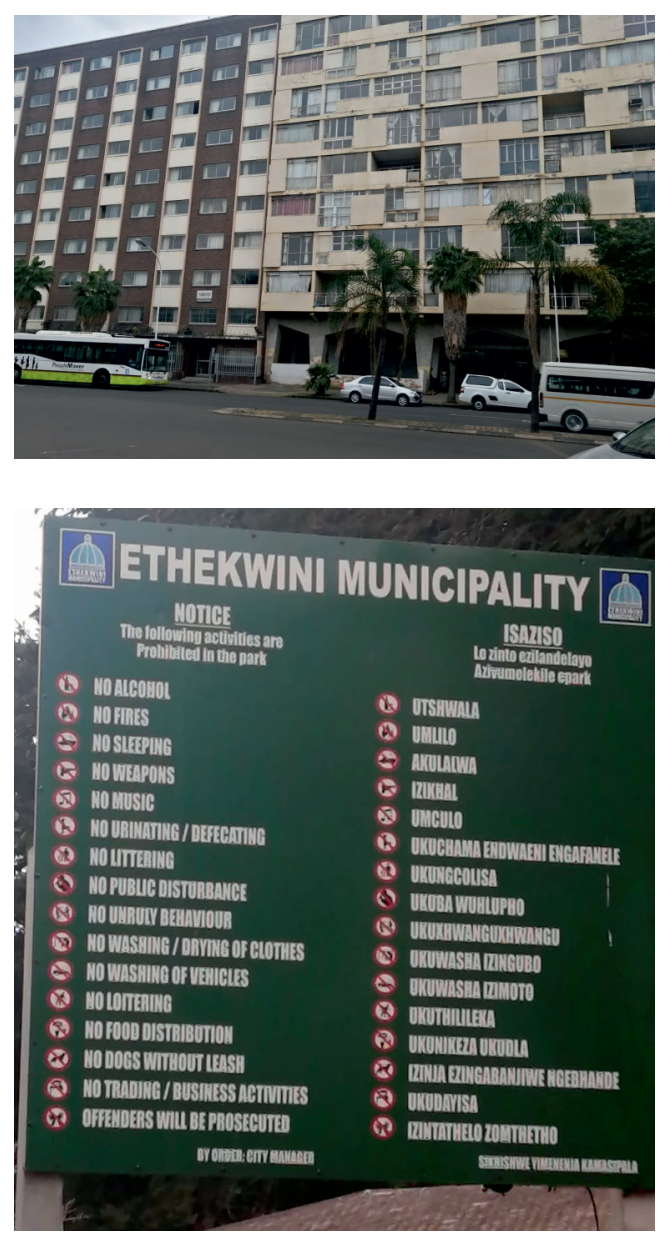

Photo 3. Dilapidated flats on Diakonia Avenue (above) and Albert Park legislation (below). (Photos by NZIMANDE, Z.D.)

is tastefully decorated and has multi-storied, well-maintained buildings and informal and formal businesses lining the pavement leading up to the park. However, the closer one moves to the Maud Mfusi Street, it becomes evident from the dilapidated buildings that iTRUMP has not yet ventured here, with the windows advertising various short-term accommodation and a makeshift mini-bus rank at the corner of Maud Mfusi and Alexandra Street. The paving in Diakonia Avenue and not in Maud Mfusi Street serves to entrench

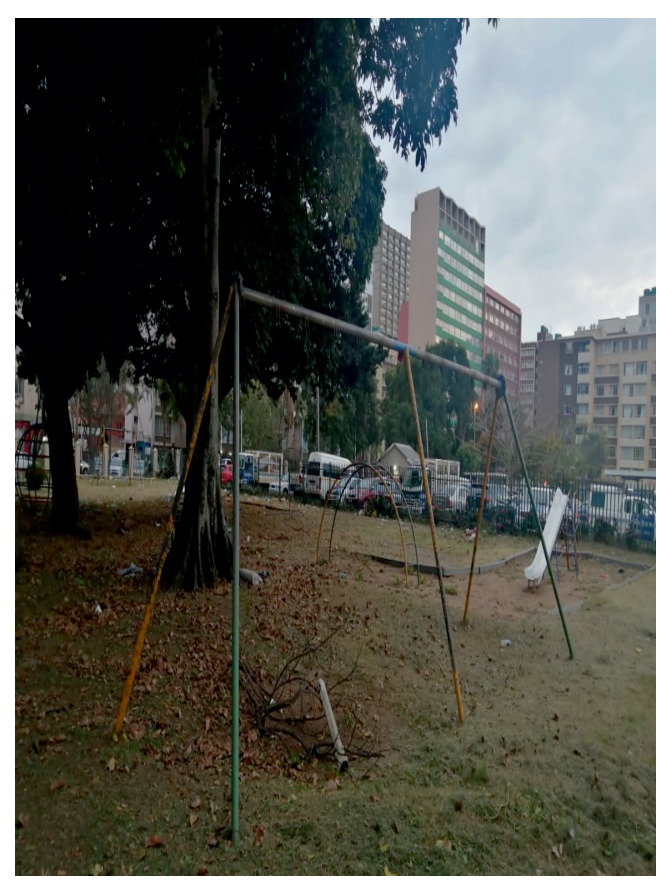

Photo 4. Unutilised park with removed swings (Photo by Nzimande, Z.D.)

and exacerbate the spatial and social division between these two streets.

One of the projects in the area is the Port View Complex owned by SOCHO Property Investment. This non-profit organisation is one of the Section 21 companies responsible for the development, distribution and management of subsidised housing across South Africa. As part of the National and Provincial government plan for providing sustainable rental homes to citizens earning between EUR 92 and EUR 460 per month, Port View was one of the projects launched in 2008 to convert four old blocks into 142 one- and two-bedroom flats. The ground floor was to be utilised as an economic space with 21 commercial units available for rent. In 2012, 90 tenants were legally evicted due to their failure to pay their rent, due to an organised rent boycott that was meant to liquidate SOHCO. This jeopardised the social housing company's ability to repay its bonds (Broughton, T. 2012). 
The Qalakabusha Albert Park Intervention Programme, which was aimed at addressing the social issues in the area, was launched in 2014. Many stakeholders - NGOs, the provincial government, private sector entities, and the police - pledged to commit themselves to making Albert Park a safe, clean attractive area. The then Mayor Councillor James Nxumalo 'emphasised that the challenges of vagrancy, loitering, drug-abuse and criminal elements at Albert Park needed to be dealt with as a matter of urgency' (eThekwini Municipality, n.d.). As such, the Albert Park is now much safer as compared to before.

\section{Comparison of the aspects of urban renewal in Budapest and Durban}

In this section, two urban renewal projects, the MQP in Budapest and the Albert Park Intervention Programme in Durban, are analysed based on the three criteria identified as being crucial to social sustainability: the structure and functioning of public-private partnership, community involvement, and project innovation and continuity. Although in this article the focus is on social participation through PPP in urban renewal, the continuity and innovation aspect is indispensable to sustainability, as one of the aims of this paper is to provide recommendations about social participation in urban renewal.

\section{Public-private partnership}

\section{Magdolna Quarter}

The EU accession of Hungary played a crucial role in acquiring an important source of investment (e.g. ERDF) for urban regeneration in most Hungarian settlements. Moreover, the local municipality, the Budapest municipality and private investors (e.g. OTP) also played an important role. Due to the complexity and uniqueness of this area-based project, there was an institutional instability between the stakeholders. Unfortunately, when the
Józsefváros municipality composition changed substantially in 2006, Rév8 had increased conflicts with the new, right-wing Fidesz-led municipal members. However, the dedication of some of the experts directly and indirectly working in the MQP, introduced innovative methods of involving the community.

\section{Albert Park}

Due to EU's interest in South Africa's 'political dialogue, trade and economic co-operation, science and technology, and development co-operation' (NJokwENI, F. 2011, 7), the Area Based Management (ABM) was partially funded by the EU with training and expert assistance also provided by the EU. While the NGOs in the Magdolna Quarter were invited by the municipality to run different social workshops, in Albert Park, the urban renewal was focused on just one main objective, the physical characteristics. As such, because of the unrest that occurred in the area when xenophobic attacks first started in 2008, to encourage dialogue, in 2009 the Nelson Mandela Foundation (NMF) joined forces with the KwaZulu-Natal (KZN) Christian Council, the KZN Refugee Council, the Refugee Social Services, the Union of Refugee Women, and Abahlali BaseMjondolo to host workshops on social cohesion between the residents to provide a space where community members could identify and discuss the different issues that they were facing in the area (NMF, 2009).

\section{Community involvement}

Magdolna Quarter

The social cohesion in the Magdolna Quarter Project was established through the active volunteering of the residents to assist in the renovation activities and by being given the opportunity to have input at public meetings. During the first phase of the housing project, the Four Buildings Association was established to represent the interests of residents; however, 
it was later dismantled for unknown reasons, after which a locally based NGO (Nap Klub) took over as a meditator to express the resident grievances to Rév8. However, despite this, public participation was somewhat challenging to community members as they had never been able to express their opinions before. The high level of mistrust in the local government also encouraged citizen participation (KERESZTÉLY, K. and Scoтt, J.W. 2012). Local meetings, community maintenance of the new and improved green spaces and shared community responsibilities such as painting the buildings and constructing the public furniture all allowed the community to be involved in the MQP.

An NGO, called the Association for Teleki Square, was founded by the locals to actively participate in the planning and maintenance of the square. This project has been hailed as one of the few best practice community participation projects by architects, the media and the local municipality. However, it has also been criticised because of its exclusion of the marginalised groups in the community because only lower-middle class Hungarians were involved in spearheading the design and functionality process for the park (JELINEK, C. 2017).

\section{Albert Park}

The community members were fairly engaged with the local government through the ward meetings and other initiatives. However, separate projects ran by NGOs had higher resident involvement as compared to those ran by the municipality (NMF, 2009).

\section{Project innovation and continuity}

\section{Magdolna Quarter}

This program was the first of its kind in Hungary, inspired by Birmingham's urban renewal programme and the 'Soziale Stadt' programme in Germany and has been seen as a 'best practice' for an integrative form of urban renewal. The foundation of Rév8 was also an innovation in the Hungarian context, the idea of which was adopted from Western Europe (Rotterdam). The complexity of this socially sensitive project meant that key stakeholders had to decide on new, innovative methods to ensure longterm project sustainability; however, after the completion of the third phase, some services were terminated due to a lack of funds, which pointed to the need for longer term planning.

\section{Albert Park}

Over 5 years have passed since the finalisation of the then latest urban rehabilitation; however, this area is still experiencing major problems such as vagrancy, high crime levels, drug trafficking, outstanding levies and a general rise in urban decay. Unscrupulous landlords are still continuing to exploit residents due to the lack of employment in the area, and property owners, who sometimes resort to violent means to get their rent, are charging exorbitant rental fees for overcrowded flats that lack basic services (MoHAMED, S.I. 1999). The tenants are reluctant to take legal action against the landlords for fear of getting arrested and/or evicted, with the illegal immigrants usually bearing the brunt of these exploitations. Furthermore, due to the Qalakabusha programme, the large group of homeless men that used to inhabit the recreational park were removed by the Metro Police and have moved next to the railway lines that are found $500 \mathrm{~m}$ from the park. This means that the community is now able to enjoy the green space. However, due to the current COVID-19 pandemic, the park is used to provide temporary shelter for homeless people by the Municipality.

\section{Discussion: lessons from the urban renewal projects in Magdolna Quarter and Albert Park}

This paper examined the importance of considering social sustainability as part of urban renewal projects, and especially scrutinised 
the role of stakeholder involvement and public participation in the conception and implementation of such projects. Both the Magdolna Quarter, Budapest (Hungary) and Albert Park, Durban (South Africa) had similar socio-economic backgrounds as both areas had been suffering from vagrancy, were generally associated with crime and grime, and were inhabited by people who had a low average education level and disadvantaged socio-economic backgrounds. Three research questions were posed on the onset and so this section aims to answer them.

Q1: How can the concept of social sustainability be defined with regards to urban renewal?

From the literature review, it is apparent that social sustainability is a complex concept, which has several dimensions, and it has no universally accepted definition. With the present paper, we did not seek to quantify and assess the social sustainability of the two studied urban renewal projects. Instead, we qualitatively explored how social sustainability was influenced by the geographical context (e.g. local social environment, levels of governance) of public participation during these relatively long-lasting projects. Based on the cases of MQP and Albert Park, it seems that the historical and geographical contexts are relevant with respect to the social sustainability of urban renewal projects. Through the inheriting of the bureaucratic institutional legacy of the Habsburg Empire and later that of state-socialism, Hungary's path divergence during the transition level gave way to convergence under the EU (Loewen, B. 2016). Similarly, South Africa has ironically shown path dependence where egalitarian policies are a way to perpetuate inequality (Friedman, S. and VAN NIEKERK, R. 2016). Experiences from Budapest and Durban are in line with other studies which emphasise the path dependency of urban regeneration (e.g. Couch, C. et al. 2011).

Furthermore, considering that the effect of path dependency and context specificity in urban policy seems to be stronger at the lower territorial levels (Moulaert, F. et al. 2007), the contribution of the present paper is twofold. First, we agree with those scholars who point to the importance of the neighbourhood as territorial analytical unit in the sustainability of urban renewal (e.g. ZHENG, H.W. et al. 2017), and further argue that more attention should be paid to the path dependency of different geographical settings in these studies. Second, the role of the EU should also be underlined in the stories of MQP and Albert Park, as in both cases the European Community supported the projects through financial and policy transfer, but specific objectives and implementation structures were tailored to local circumstances. Thus, results suggest that 'download of European policies' and 'variegated Europeanization' (CARPENTER, J. et al. 2020) can be observed not only within the EU but also outside of it. However, this phenomenon and its implications to social sustainability in urban renewal needs further investigation.

Q2: What is the relationship between the social sustainability of urban renewal interventions and the involvement and participation of various stakeholders?

Both Hungary and South Africa have comprehensive strategic, legal and policy frameworks in urban planning. In MQP, although the policies gave rise to greater PPP, community involvement was not perfect in all the different stages, but much better than before political changes in 2006. In Albert Park, despite the good policies in place, the projects saw fewer PPP, community involvement and thereafter a lack of project innovation and continuity. However, there has been more bottom-up, innovative activities occurring in the area by civil society. Therefore, the role of the state was found to be an important influential factor in the PPPs in both Hungary and South Africa. Both projects differed significantly in stakeholder involvement and the distribution of power between stakeholders. As such, MQP was criticised by some interest groups because several civil organisations were not involved in the project planning or implementation. To eliminate such problems, LeITHEISER, S. and FollmanN, A. (2020) suggest that grassroots initiatives should be encouraged by the authori- 
ties, and the involvement of such bottom-up initiatives should be formalised in urban policy.

Social sustainability can only be achieved by continual active engagement with the community in all project stages. UYSAL, Ü.E. (2012) concluded that projects that fail to engage local and affected communities risk community resistance and development delays. This was evident in Albert Park where despite rules being in place to 'control' the park activities, such as the prohibition of alcohol and drugs, it remains a 'no go zone' due to the high number of vagrants and the associated unruly behaviour. Therefore, the conception and implementation of urban renewal projects can either promote or undermine local community participation. Roberts, P. (2000) commented that the physical renovation of buildings was strongly linked to social aspects, that is, by entrenching spatial and social inequalities through poor planning, urban renewal projects can create new social problems.

One example of this was the exclusion of weaker but 'problematic groups' (mainly the homeless and the Roma) from the planning of Teleki Square (MQP). Although this green space is functioning and serves to beautify the area, it is controlled by security guards making sure that the different rules are followed (Boros, L. et al. 2016) unlike in Albert Park whereas there are no security measures in place, the park is deemed unsafe by the local community. This was further emphasised by Ho, D.C.W. et al. (2012), who found that to minimise social exclusion, community aspirations should be evaluated and assessed from project onset. Through the relatively high level of public involvement in the MQP, the residents (albeit selected) were given the opportunity to be heard; however, there was little-to-no public involvement in the Albert Park project. Therefore, the public participation was more successful in the MQP because of the effective techniques used and the large amount of work done by Rév8 and other actors. Regardless of these successes, as some disadvantaged groups remained underrepresented in the planning process, more at- tention could have been paid to these groups (JELINEK, C. 2017).

The vitality and uniqueness of neighbourhoods can often be damaged during urban renewal when the original residents are prohibited from returning. In his review paper, Thwala, W.D. (2009) discussed how the lack of management of urban renewal projects after completion was one of the major sustainability issues, indicating that effective local governance structures were required. While the strategic developmental plans in both South Africa and Hungary are normally long term, the urban renewal projects are often no more than 3-5 years. After the completion of the Magdolna Quarter and Albert Park projects, very few ex-post social studies were conducted to evaluate the positive and/ or negative impacts these projects had had on the community. Durban has implemented several policies to attract and support entrepreneurial urbanism, which have resulted in piecemeal, uncoordinated activities that have no long-term impact or sustainability.

Q3: What lessons can be learnt with relation to social sustainability from urban renewal projects implemented in different geographical contexts?

Firstly, while public participation does not follow a rigorous approach, the greater the participation, the higher the chance that a project's objectives will be met. However, deeper public participation is not always straightforward, as this process can be tedious, time-consuming and complex (Thwala, W.D. 2009). Although often said, decisionmakers should employ tailor-made, appropriate approaches to projects as conventional methods adopted from western countries are often ill-fitted as they do not take into account local traditions. For example, in MQP, civil society has played a huge role in supporting activities as bureaucracies often struggle to bring about required, radical transformation in cities. Of course, the financial investment for projects allow such NGOs to apply for grants to work in the area. In Durban, it is not an impossible scenario as the Warwick Junction urban renewal project has been internationally recognised as a good practice 
due to the collaborative process with street traders and authorities to transform the space. However, besides the Asiye eTafuleni NGO working in this space, the city lacks the presence of well-established civil society organisations (Bond, P. and MotTiar, S. 2018; Sutherland, C. et al. 2018).

Secondly, impact assessments, such as social impact assessment, that allow community members and other relevant stakeholders to discuss socio-economic impacts of developments should be mandated in environmental legislation. Moreover, such legislation must go beyond being 'on paper' as proper, follow-up strategies should be employed to enhance social integration and assist in reducing potential community resistance to projects from inception to completion (YeUnG, S.C.W. et al. 2007).

Lastly, limited vision, inspiration and focus to promote inner city districts and attract higher investment through urban renewal is one of the biggest weakness of local municipalities. In their paper, Turok, I. et al. (2019) attributed the lack of urban renewal in Durban to municipal indecision, poor delivery of basic services and general laissezfaire attitude towards urban decay. Driven motivation to decrease urban decay while increasing social inclusion and investment increases the success rate of projects. Durban has great opportunity to attract investors, however the high levels of corruption, poor coordination between governmental departments, and misaligned and discordant PPP all contribute to making investors hesitate to invest in the area.

\section{Future research prospects and conclusions}

This paper focused on socially sustainable urban renewal through an examination of two case studies in Budapest and Durban and a discussion on the different project aspects. While it was found that substantial progress had been made in involving communities in these urban renewal projects, the socio-economic impacts of these projects have not yet been adequately explored. Urban renewal plays a vital role in rejuvenating dilapidated buildings and attracting investors to the area, and thereafter improving community health and safety in the long run. However, local participation and social sustainability of projects may not be secondary considerations to public authorities as it is important to balance the interests of all stakeholders involved. As such, the on-going debate on urban renewal as gentrification, the right to city, and community engagement through social inclusion and exclusion is better understood in the context of micro-cases on disadvantaged communities. Although it could be argued that the social dimension is being incorporated into more urban renewal projects, the scale and level of this community engagement is far from satisfactory. Therefore, more studies are needed that examine the possibilities for effective sustainable community urban renewal governance.

Acknowledgements: The authors would like to thank the South African Department of Higher Education and Training for financial support. We would also like to thank the anonymous reviewers for their constructive input in improving the paper.

\section{REFERENCES}

Alföldi, G., Benkő, M. and Sonkoly, G. 2019. Managing urban heterogeneity: A Budapest case study of historical urban landscape. In Reshaping Urban Conservation. Ed.: Roders, A.P. and BAndarin, F., Singapore, Springer, 149-166.

Basiago, A.D. 1998. Economic, social, and environmental sustainability in development theory and urban planning practice. Environmentalist 19. (2): 145-161.

BoDnár, J. and Böröcz, J. 1998. Housing advantages for the better connected? Institutional segmentation, settlement type and social network effects in Hungary's late state-socialist housing inequalities. Social Forces 76. (4): 1275-1304.

Bond, P. and Mottiar, S. 2018. Terrains of civil and uncivil society in post-apartheid Durban. Urban Forum 29. (4): 383-395.

Boros, L., Fabula, Sz., Horváth, D. and Kovács, Z. 2016. Urban diversity and the production of public space in Budapest. Hungarian Geographical Bulletin 65. (3): 209-224. 
Broughton, T. 2012. Developers fight estate 'hijacking'. Available at https://www.iol.co.za/news/ developers-fight-estate-hijacking-1266306

Carpenter, J., Medina, M.G., Garcia, M.Á.H. and Hurtado, S.D.G. 2020. Variegated Europeanization and urban policy: Dynamics of policy transfer in France, Italy, Spain and the UK. European Urban and Regional Studies 27. (3): 227-245.

Colantonio, A. 2011. Social sustainability: Exploring the linkages between research, policy and practice. In European Research on Sustainable Development. Eds.: JAEger, C., TÀbara, J. and JAEger, J., Berlin, Springer, 35-58.

Colantonio, A., Dixon, T., Ganser, R., Carpenter, J. and Ngombe, A. 2009. Measuring Socially Sustainable Urban Regeneration in Europe. Final Report. Oxford, Oxford Institute for Sustainable Development (OISD), Oxford Brookes University.

Couch, C., Sykes, O. and Börstinghaus, W. 2011. Thirty years of urban regeneration in Britain, Germany and France: The importance of context and path dependency. Progress in Planning 75. (1): 1-52.

Csanádi, G., Csizmady, A. and Olt, G. 2011. Social sustainability and urban renewal on the example of Inner-Erzsébetváros in Budapest. Society and Economy 33. (1): 199-217.

Darchen, S. and LAdouceur, E. 2013. Social sustainability in urban regeneration practice: A case study of the Fortitude Valley Renewal Plan in Brisbane. Australian Planner 50. (4): 340-350. Doi: 10.1080/07293682.2013.764909

Dempsey, N., Bramley, G., Power, S. and Brown, C. 2011. The social dimension of sustainable development: Defining urban social sustainability. Sustainable Development 19. (5): 289-300. Doi: $10.1002 / \mathrm{sd} .417$

Donaldson, R. and du Plessis, D. 2013. The urban renewal programme as an area-based approach to renew townships: The experience from Khayelitsha's Central Business District, Cape Town. Habitat International 39. 295-301.

Enyedi, Gy. and PÁlné Kovács, I. 2008. Regional changes in the urban system and governance responses in Hungary. Urban Research and Practice 1. (2): 149-163.

Erwin, K. 2018. Albert Park: A world in a city block. L'architettura delle città - The Journal of the Scientific Society Ludovico Quaroni. North America, 10 mar. 2018. Available at http://architetturadellecitta.it/ index.php/adc/article/view/193

eThekwini Municipality, n.d. Stakeholders Pledge to Eradicate Social Ills at Albert Park. Available at http:// www.durban.gov.za/Resource_Centre/new2/ Pages/Stakeholders-Pledge-To-Eradicate-SocialIlls-at-Albert-Park.aspx

Földi, Z. and KovÁcs, Z. 2014. Neighbourhood dynamics and socio-spatial change in Budapest. Europa Regional 19. (3-4): 7-20.
Frenzel, F. 2014. December. Slum tourism and urban regeneration: Touring inner Johannesburg. Urban Forum 25. (4): 431-447.

Friedman, S. and van NIEKERK, R. 2016. Introduction: social policy post 1994 in South Africa. Transformation: Critical Perspectives on Southern Africa 91. (1): 1-18.

Geróházi, É., Somogyi, E., Szemző, H. and Tosics, I. 2004. A szociális városrehabilitáció: koncepció, eszközrendszer és modellkísérletek (Socially aimed urban renewal: concept, tools and pilot projects). Budapest, VÁTI.

Glasson, J. and Wood, G. 2009. Urban regeneration and impact assessment for social sustainability. Impact Assessment and Project Appraisal 27. (4): 283-290. Doi: 10.3152/146155109X480358

Gregory, J.J. 2016. Creative industries and urban regeneration - The Maboneng precinct, Johannesburg. Local Economy 31. (1-2): 158-171.

Griessler, E. and LitTIG, B. 2005. Social sustainability: a catchword between political pragmatism and social theory. International Journal for Sustainable Development 8. (1-2): 65-79.

Harada, Y. and Jørgensen, G. 2016. Area-based urban regeneration comparing Denmark and Japan. Planning Practice E Research 31. (4): 359-382.

Ho, D.C.W., Yau, Y., Law, C.K., Poon, S.W., YiP, H.K. and LiUsman, E. 2012. Social sustainability in urban renewal: An assessment of community aspirations. Urbani izziv 23. (1): 1-125.

Holden, M. 2011. Public participation and local sustainability: Questioning a common agenda in urban governance. International Journal of Urban and Regional Research 35. (2): 312-329. Doi: 10.1111/j.1468-2427.2010.00957.x

Holden, M. 2012. Urban policy engagement with social sustainability in metro Vancouver. Urban Studies 49. (3): 527-542. Doi: 10.1177/0042098011403015

Houghton, J. 2011. Negotiating the global and the local: evaluating development through public-private partnerships in Durban, South Africa. Urban Forum 22. (1): 75-93.

JelineK, C. 2017. Uneven development, urban policy making and brokerage. Urban rehabilitation policies in Hungary since the 1970s. PhD dissertation, Budapest, Central European University.

Jin, E., LeE, W. and KIM, D. 2018. Does resident participation in an urban regeneration project improve neighbourhood satisfaction: A case study of "Amichojang" in Busan, South Korea. Sustainability 10. (10): 3755-3667.

Keresztély, K. 2017. From social urban renewal to discrimination: Magdolna neighbourhood programme in Budapest. Cities, Territories, Governance-CITEGO. Available at http://www.citego.org/bdf_fichedocument-555 en.html

Keresztély, K. and SCott, J.W. 2012. Urban regeneration in the post-socialist context: Budapest and the search for a social dimension. European Planning Studies 20. (7): 1111-1134. 
Klijn, E.H. and Teisman, G.R. 2003. Institutional and strategic barriers to public-private partnership: An analysis of Dutch cases. Public Money and Management 23. (3): 137-146.

Koppenjan, J.F. and Enserink, B. 2009. Public-private partnerships in urban infrastructures: reconciling private sector participation and sustainability. Public Administration Review 69. (2): 284-296.

KovÁcs, Z. 2009. Social and economic transformation of historical neighbourhoods in Budapest. Tijdschrift voor Economische en Sociale Geografie 100. (4): 399-416.

Kovács, Z. and Herfert, G. 2012. Development pathways of large housing estates in post-socialist cities: An international comparison. Housing Studies 27. (3): 324-342.

KRIŽNIK, B. 2018. Transformation of deprived urban areas and social sustainability: A comparative study of urban regeneration and urban redevelopment in Barcelona and Seoul. Urbani izziv 29. (1): 83-95.

LeE, G.K.L. and ChAN, E.H.W. 2010. Evaluation of the urban renewal projects in social dimensions. Property Management 28. (4): 257-269. Doi: $10.1108 / 02637471011065683$

Leitheiser, S. and Follmann, A. 2020. The social innovation-(re)politicisation nexus: Unlocking the political in actually existing smart city campaigns? The case of Smart City Cologne, Germany. Urban Studies 57. (4): 894-915.

Lichtenberger, E., Cséfalvay, Z. and Paal, M. 1995. Várospusztulás és felújítás Budapesten (Urban decline and renewal in Budapest). Budapest, Magyar Trendkutató Központ.

LocsmáNDI, G. 2011. Large-scale restructuring processes in the urban space of Budapest. In Urban Models and Public-Private Partnership. Ed.: LongA, R.D., Berlin, Springer, 131-212.

Loewen, B. 2016. On the path dependence of regional policy in Central and Eastern Europe. In European Week of Regions and Cities University Master Class. Book of Papers. Brussels, RSA-AESOP, 220-231.

Mbanjwa, P. 2018. The socio-economic impacts of government's urban renewal initiatives: the case of Alexandra Township. Masters Thesis. Cape Town, University of Cape Town.

McKenzie, S. 2004. Social Sustainability: Towards Some Definitions. Adelaide, AUS, Hawke Research Institute, Working Paper Series, No 27.

Mendel, S.C. and Brudney, J.L. 2012. Putting the NP in PPP: The role of non-profit organizations in public-private partnerships. Public Performance $\mathcal{E}$ Management Review 35. (4): 617-642.

Mhlekude, N. 2013. Assessment of the impact of the Mdantsane urban renewal programme on the lives and livelihoods of beneficiaries (2001-2011): the case of the eastern cape Buffalo City Metropolitan Municipality. Masters Thesis. Alice, University of Fort Hare.
Mohamed, S.I. 1999. Report on the Rental Survey and Profile of Buildings in Albert Park. Durban, The Organisation of Civic Rights. Available at http:// docplayer.net/123782552-Report-on-the-rental-survey-and-profile-of-buildings-in-albert-park.html

Moulaert, F., Martinelli, F., González, S. and SwYNGEDouw, E. 2007. Introduction: social innovation and governance in European cities. Urban development between path dependency and radical innovation. European Urban and Regional Studies 14. (3): 195-209.

Musakwa, W. 2008. Local economic development as a poverty alleviation tool: A case study on the urban renewal program in KwaMashu, Durban. Doctoral Thesis. Durban, University of KwaZulu-Natal.

Ndlela, A.P. 2013. Examining Public Participation in PostApartheid Spatial Development Planning Projects. A case study of the KwaMashu Urban Renewal Project. Masters Thesis. Durban, University of KwaZulu-Natal.

NMF 2009. Community conversation in Albert Park builds social cohesion. Houghton, Johannesburg, Nelson Mandela Foundation. Available at https:// www.nelsonmandela.org/news/entry/communityconversation-in-albert-park-builds-social-cohesion

Njokweni, F. 2011. Area-based management experiences: 20 lessons learned from eThekwini Municipality, Durban South Africa, 2003-2008. Durban, Corporate Policy Unit.

Rahardjo, H.A., Suryani, F. and Trikariastoto, S.T. 2014. Key success factors for public private partnership in urban renewal in Jakarta. International Journal of Engineering and Technology 6. (3): 217-219.

Roberts, P. 2000. Evolution, definition and purpose of urban regeneration. In Urban Regeneration: $A$ Handbook. Eds.: Roberts, P. and SyKes, H., London, Sage, 9-36.

Roseland, M. 1998. Toward Sustainable Communities: Resources for Citizens and their Communities. Gabriola Island, BC, New Society Publishers.

SONA, 2001. President Mbeki, State of the Nation Address. South African History Online. Available at https://www.sahistory.org.za/archive/2001-president-mbeki-state-nation-address-9-february-2001

South African Revenue Service, 2014. Guide to the Urban Development Zone (UDZ) Tax Incentive. Issue 4. Available at https://www.thesait.org.za/ news/191198/Guide-on-the-Urban-DevelopmentZone-Tax-Incentive-Issue-4.htm

Sutherland, C., Scott, D., Nel, E. and Nel, A. 2018. Conceptualizing 'the urban' through the lens of Durban, South Africa. Urban Forum 29. (4): 333-350.

SzelÉNyi, I. 1990. Városi társadalmi egyenlötlenségek (Urban social inequalities). Budapest, Akadémiai Kiadó.

Teller, N. 2015. Local governance, socio-spatial development and segregation in post-transition Hungary. Serbian Architectural Journal 7. (3): 285-298. 
Thwala, W.D. 2009. Experiences and challenges of community participation in urban renewal projects: The case of Johannesburg, South Africa. Journal of Construction in Developing Countries 14. (2): 37-54.

Tosics, I. 2006. Spatial restructuring in post-socialist Budapest. In The Urban Mosaic of Post-Socialist Europe. Space, Institutions and Policy. Eds.: Tsenkova, S. and Nedović-Budić, Z., Heidelberg, PhysicaVerlag, 131-150.

Turok, I., Seeliger, L. and Visagie, J. 2019. Restoring the core? Central city decline and transformation in the South. Progress in Planning 100434. Doi: 10.1016/j.progress.2019.100434

UySAL, Ü.E. 2012. An urban social movement challenging urban regeneration: The case of Sulukule, Istanbul. Cities 29. (1): 12-22.

Warsen, R., Nederhand, J., Klijn, E.H., Grotenbreg, S. and Koppenjan, J. 2018. What makes public private partnerships work? Survey research into the outcomes and the quality of cooperation in PPPs. Public Management Review 20. (8): 1165-1185.

WonG, L.K. and YU, P.H. 2015. Urban renewal and social sustainability: An exploratory study of the urban life of Wan Chai. SpringerPlus 4. (Suppl. 2): P5. Doi: 10.1186/2193-1801-4-S2-P5

YeUnG, S.C.W., LAU, K.K.L. and TANG, B.B.S. 2007. The application of social impact assessment in urban planning and development - the Australian experience. Hong Kong, Department of Building and Real Estate, Polytechnic University. Available at https:// www.asres2007.um.edu.mo/papers/150\%20-\%20 PAPER.pdf
Yi, Z., Liv, G., Lang, W., Shrestha, A. and Martek, I. 2017. Strategic approaches to sustainable urban renewal in developing countries: A case study of Shenzhen, China. Sustainability 9. (8): 1460-1479.

Young, J. 2018. Property regeneration and growth through tax incentives. Global Africa Network. Available at https://www.globalafricanetwork.com/2018/06/27/ company-news/property-regeneration-andgrowth-through-tax-incentives/

ZHENG, H.W., SHEN, G.Q. and WANG, H. 2014. A review of recent studies on sustainable urban renewal. Habitat International 41. 272-279.

Zheng, H.W., Shen, G.Q,P., Song, Y., Sun, B. and HonG, J. 2017. Neighbourhood sustainability in urban renewal: An assessment framework. Environment and Planning B: Urban Analytics and City Science 44. (5): 903-924.

ZIJUn, Y.E. 2019. Review of the basic theory and evaluation methods of sustainable urban renewal. IOP Conference Series. Earth and Environmental Science 281. 012017. Doi:10.1088/1755-1315/281/1/012017 